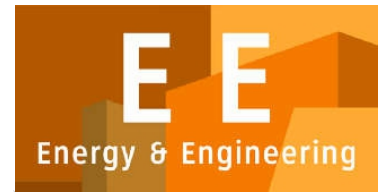

PAPER - OPEN ACCESS

\title{
Kajian Aspek Partisipasi Masyarakat Pada Kawasan Ekowisata Tangkahan
}

$\begin{array}{ll}\text { Author } & : \text { Nurlisa Ginting, dkk } \\ \text { DOI } & : 10.32734 / \text { ee.v2i1.412 } \\ \text { Electronic ISSN } & : 2654-704 \mathrm{X} \\ \text { Print ISSN } & : 2654-7031\end{array}$

Volume 2 Issue 1 - 2019 TALENTA Conference Series: Energy \& Engineering (EE)

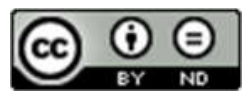

This work is licensed under a Creative Commons Attribution-NoDerivatives 4.0 International License.

Published under licence by TALENTA Publisher, Universitas Sumatera Utara

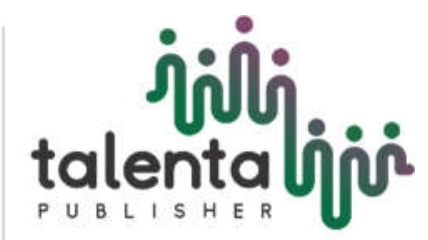


talentanj

Available online at https://talentaconfseries.usu.ac.id

\title{
Kajian Aspek Partisipasi Masyarakat Pada Kawasan Ekowisata Tangkahan
}

\author{
Nurlisa Ginting ${ }^{1,2, *}$, M.Rizky ${ }^{1}$, Christi R.Siregar ${ }^{1}$, Erni Triska ${ }^{1}$, Putri Ayu ${ }^{1}$, William Surya ${ }^{1}$, \\ Pratiwi $^{1}$ \\ ${ }^{l}$ Departemen Arsitektur, Fakultas Teknik Universitas Sumatera Utara, Jalan. Perpustakaan, Kampus USU Gedung D, Padang Bulan, Medan Baru, Kota Medan, \\ Sumatera Utara 20155, Indonesia \\ ${ }^{2}$ Kelompok Kerja Pariwisata Kawasan Danau Toba dan Pariwisata Berkelanjutan, Universitas Sumatera Utara.
}

*nurlisa@usu.ac.id,mr.a24rizky@gmail.com, Christirayani@gmail.com, Ernitriska@gmail.com, pratiwiningtyas@gmail.com, putriayu@gmail.com

\begin{abstract}
Abstrak
Tangkahan merupakan pariwisata yang menerapkan konsep ekowisata. Salah satu aspek pembentuk ekowisata pada kawasan Tangkahan ini adalah partisipasi dari masyarakat lokalnya. Dengan adanya partisipasi masyarakat lokal dalam mengelola kawasan Tangkahan, maka dapat memberi profit tersendiri bagi masyarakatnya. Tujuan dari penelitian ini untuk mengidentifikasi aspek partisipasi masyarakat yang ada di kawasan Ekowisata Tangkahan dan menemukan kekurangan aspek partisipasi masyarakat sebagai rekomendasi bagi masyarakat Tangkahan dalam proses pengembangan kawasan Ekowisata Tangkahan. Aspek partisipasi masyarakat di kawasan Tangkahan didasarkan pada adanya otoritas yang mengorganisir kawasan Ekowisata Tangkahan ; adanya layanan jasa yang disediakan masyarakat lokal kepada wisatawan ; dan keterlibatan masyarakat dalam perencanaan, pelaksanaan, pemantauan, serta evaluasi kawasan ekowisata. Dalam meneliti aspek partisipasi masyarakat pada kawasan Tangkahan, hal mendasar yang dilakukan adalah membuat kajian teori tentang aspek partisipasi masyarakat di kawasan Ekowisata yang kemudian di dukung dengan hasil observasi lapangan yang kemudian diperkuat dengan penyebaran kuesioner terhadap wisatawan dan masyarakat lokal guna mengetahui persepsi masyarakat dan wisatawan tentang bagaimana aspek partisipasi masyarakat dalam pengembangan ekowisata di Tangkahan.
\end{abstract}

Kata kunci : tangkahan; ekowisata; partisipasi masyarakat

Abstract

Tangkahan is tourism that applies the concept of ecotourism. One aspect of forming ecotourism in the Tangkahan area is the participation of local communities. With the participation of the local community in managing the Tangkahan area, it can provide its own profit for the community. The purpose of this study was to identify aspects of community participation in the Tangkahan Ecotourism area and find a lack of points of community participation as a recommendation for the Tangkahan community in the process of developing the Tangkahan Ecotourism area. The aspect of community participation in the Tangkahan area is based on the existence of an authority that organizes the Tangkahan Ecotourism area; services provided by the local community to tourists; and community involvement in planning, implementing, monitoring and evaluating ecotourism areas. In examining aspects of community participation in the Tangkahan area, the essential thing to do is to make a theoretical study of issues of community participation in the Ecotourism area which is then supported by the results of field observations which are then reinforced by distributing questionnaires to tourists and local communities to find out perceptions of the community and tourists how aspects of community participation in developing ecotourism in Tangkahan.

Keywords: tangkahan; ecotourism; society participation

\section{Pendahuluan}

Kawasan Tangkahan adalah kawasan yang terletak ditaman nasional Gunung Leuser (TNGL), Kabupaten Langkat, Sumatera Utara. Tangkahan Berada diantara desa Namo Sialang dan Desa Sei Serdang. Kawasan Tangkahan pada awal abad ke 20 (tahun 1900 an) merupakan kawasan hutan yang terdiri dari hutan lindung (natur reservaat) dan hutan produksi dimana masyarakat lokalnya dahulu berpindah pindah untuk memenuhi kebutuhan rumah tangga, kayu bakar, berburu dan lainnya merupakan bahagian dari pemenuhan kebutuhan sehari-hari dalam budaya kearifan tradisional. Pada pertengahan 1980 sampai 1990 an sebagian kelompok dominan (illegal logger) dengan pemodal baru menebang wilayah penebangan kelompok lain 
menyebabkan konflik horizontal. Pada tahun 2001, masyarakat Tangkahan sepakat untuk mengembangkan kawasan Tangkahan menjadi kawasan Ekowisata.

\subsection{Partisipasi Masyarakat}

Partisipasi masyarakat sangat penting dalam pengelolaan kawasan ekowisata. Partisipasi masyarakat dianggap penting dikarenakan dapat berpengaruh pada pendapatan bagi masyarakat itu sendiri, dan juga masyarakat dapat ikut turut serta dalam menjaga lingkungan dan mengkonservasi alam sekitar kawasan ekowisata [1].

Partisipasi masyarakat dalam pelaksanaan kawasan ekowisata adalah sebagai berikut (1) Partisipasi pemikiran berupa sumbangan ide atau pendapat dalam pengelolaan suatu Ekowisata. Contohnya seperti adanya otoritas yang mengorganisir pengelolaan kawasan Ekowisata; (2) Partisipasi tenaga diberikan dalam bentuk tenaga untuk pelaksanaan usaha - usaha yang dapat menunjang keberhasilan suatu pengelolaan Ekowisata. Contohnya seperti jasa atau layanan. (3) Partisipasi keterampilan diberikan dalam bentuk partisipasi masyarakat dalam memamerkan kerajinan lokal sebagai salah satu daya tarik wisata [2].

Tingkat partisipasi masyarakat terbagi dari yang paling rendah hingga yang paling tinggi. Pada tingkatan terendah, partisipasi masyarakat masih bersifat pasif. Manajer konservasi dan perencana luar mempromosikan partisipasi kegiatan dalam rangka kegiatan konservasi. Pada tingkat berikutnya, masyarakat lebih banyak mengambil peran yang membuat keputusan sehingga memiliki kendali yang lebih besar. Pada tingkat tertinggi, masyarakat memiliki inisiatif dalam melakukan tindakan dan pengambilan keputusan yang lebih dominan. Tingkat partisipasi masyarakat dapat dilihat pada kegiatan berikut: (a) Penciptaan inisiatif konservasi ; (b) Perancangan rencana pengelolaan; (c) Pelaksanaan kegiatan konservasi di daerah tersebut [3].

Partisipasi masyarakat terdiri dari aspek otoritas yang mengorganisir kawasan ekowisata, aspek layanan jasa dari masyarakat lokal, dan aspek keterlibatan masyarakat dalam perencanaan, pelaksanaan, pemantauan, serta evaluasi kawasan ekowisata. (Gambar 1.1)

\subsection{Otoritas Yang Mengorganisir Kawasan Ekowisata}

Institusi atau suatu Organisasi pada suatu kawasan bertugas untuk menciptakan lingkungan politik dan hukum yang kondusif, sektor swasta membuka lapangan pekerjaan dan memberikan pendapatan, serta masyarakat yang berperan dalam membangun interaksi sosial, ekonomi, dan politik serta mengorganisir seluruh kegiatan yang ada pada suatu kawasan Ekowisata [4]. Pengelolaan dari organisasi terhadap suatu ekowisata menerapkan pendepatan konservasi terhadap lingkungan sehingga alam sekitar Ekowisata tetap terjaga [5]. Pendekatan Co-Management atau pengelolaan bersama merupakan salah satu cara yang ampuh untuk mengelola sumber daya alam dimana ruang terbuka hijau menjadi lahan yang perlu di konservasi secara bersama (kemitraan) antara pemerintah, masyarakat, dan stakeholder. Pendekatan ini sendiri juga di sebut sebagai pengelolaan partisipatif. Pengelolaan ini dibagi atas tiga bagian utama yaitu: (a) Semua yang memegang peran stakeholder diberi kesempatan untuk terlibat aktif dalam pengelolaan. Hal ini dimaksud dengan tujuan untuk menjamin komitmen dan partisipasi serta untuk menampung pengetahuan, aspirasi dan pengalaman dalam pengelolaan; (b) Pembagian peran dan tanggung jawab di dalam pengelolaan yang berbeda-beda tergantung dari kondisi tiap kawasan [6].

Peluang keterlibatan masyarakat akan menjadikan masyarakat diberdayakan dan melaksanakan fungsi kontrol dari tindakan para pengambil keputusan agar bertanggung jawab serta dapat pula mempertanggungjawabkan keputusan-keputusan mereka. Hal ini pada akhirnya akan berdampak positif bagi upaya pemberantasan korupsi, peningkatan pelayanan, dan memastikan bahwa sumber daya digunakan secara efisien [7]. Lembaga sebagai suatu organisasi yang dibentuk oleh atau ada hubungannya dengan pemerintah dan atau terdaftar pada Lembaga Negara serta memiliki aturan-aturan formal seperti Anggaran Dasar (AD) dan Anggaran Rumah Tangga (ART) [8]. Aspek Otoritas yang mengorganisir kawasan ekowisata terdiri dari adanya hukum sehingga lingkungan kondusif, terciptanya lapangan kerja, upaya konservasi, adanya pembagian tugas. (Gambar 1.1)

\subsection{Layanan jasa dari masyarakat lokal}

Kapabilitas masyarakat dalam mengelola ekowisata sangat penting karena masyarakat lokal merupakan aktor kunci dalam pengembangan ekowisata dimana berperan sebagai penyedia atraksi wisata dan penentu kualitas produk wisata tersebut [9]. Dalam meningkatkan mutu produk ekowisata dibutuhkan peran masyarakat setempat dengan mengelola sumber daya alam yang ada. Untuk peningkatan sumber daya manusia diadakan pelatihan untuk meningkatkan pengetahuan dan wawasan masyarakat tentang pengelolaan ekowisata : (a) Layanan Jasa dalam bentuk tenaga_Peranan dan keterlibatan masyarakat dalam mengelola seperti pemandu maupun memasarkan produk-produk ekowisata yang dikelola oleh suatu kawasan ; (b) Layanan Jasa dalam bentuk keterampilan:Meningkatkan peran dan partisipasi masyarakat dalam memanfaatkan sumber daya yang ada untuk dijadikan sebuah usaha dengan tujuan memperoleh keuntungan ekonomi, sosial, maupun budaya dari pembangunan ekowisata [10].

Layanan jasa dari masyarakat lokal juga harus terdapat aspek sebagai berikut : (a) Dengan dikaitkan dengan teori bisnis yang memberikan slogan "pembeli adalah raja", kegiatan ekowisata hampir seluruhnya mengandung unsur pelayanan yang optimal; (b) Dalam melayani wisatawan masyarakat lokal menciptakan suasana ramah, menarik, sopan, dan sifat kekeluargaan; (c) Tersedianya berbagai jenis fasilitas yang berasal dari masyarakat lokal ; (d) Memberikan konstribusi dalam hal mengelola produk ekowisata. Aspek Layanan jasa dari masyarakat lokal terdiri dari atraksi wisata, pemandu, layanan jasa yang bagus, dan keramahan penyedia jasa. (Gambar 1.) 


\subsection{Keterlibatan masyarakat dalam perencanaan, pelaksanaan, pemantauan, serta evaluasi kawasan Ekowisata}

Untuk menumbuhkan partisipasi masyarakat, maka perlu diciptakan suasana kondusif, yakni situasi yang menggerakkan masyarakat untuk menarik perhatian dan kepedulian pada kegiatan ekowisata dan kesediaan bekerjasama secara aktif dan berkelanjutan [11]. Keterlibatan masyarakat dalam perencanaan akan menciptakan hasil yang lebih baik, sehingga rasa tanggung jawab bersama akan terbina yang nantinya menghasilkan kerja baik. Keterlibatan masyarakat dalam perencanaan akan menciptakan hasil yang lebih baik, sehingga rasa tanggung jawab bersama akan terbina yang nantinya menghasilkan kerja baik [12]. Keterlibatan masyarakat dalam pemantauan aktivitas pada kawasan ekowisata meliputi juga pemantauan terhadap budaya - budaya lokal yang terdapat pada kawasan. Pengawasan terhadap budaya - budaya ini dimaksudkan untuk menghindari hilangnya kebudayaan asli sekitar kawasan [13]. Aspek Keterlibatan masyarakat dalam perencanaan, pelaksanaan, pemantauan, serta evaluasi kawasan ekowisata terdiri dari masyarakat terlibat dalam perencanaan, pelaksanaan, pemantauan, serta evaluasi dan pemantauan terhadap budaya lokal. (Gambar 1).

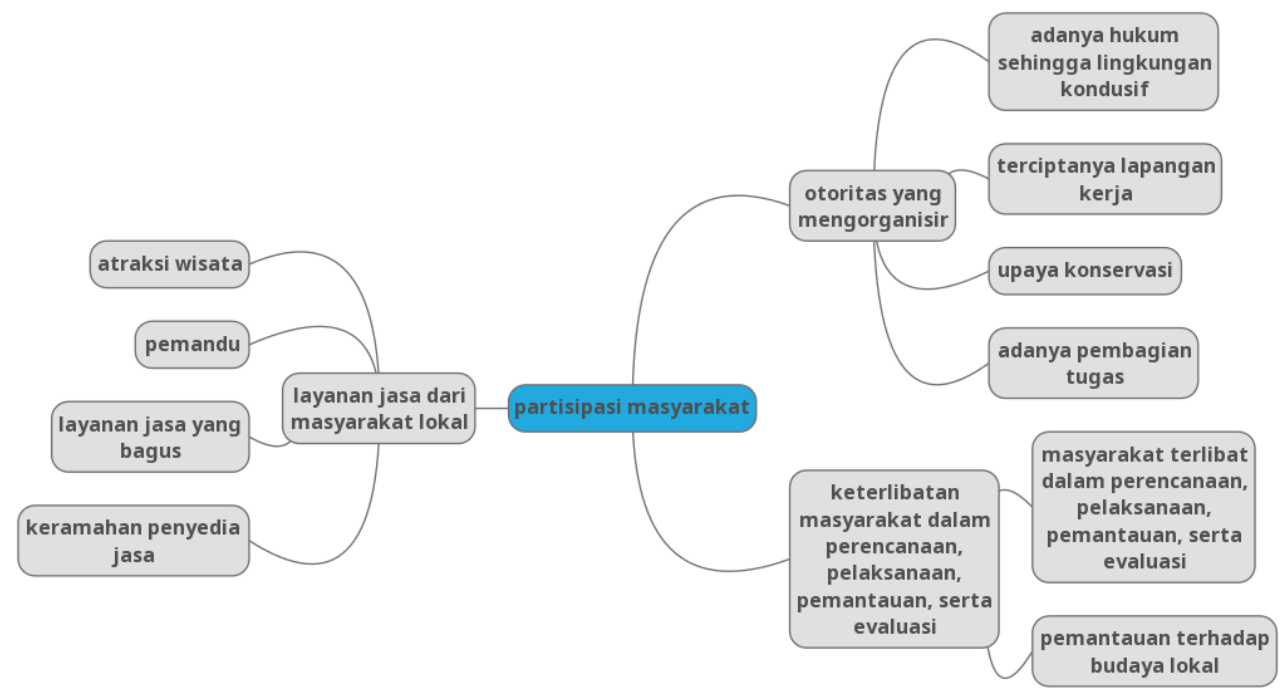

Gambar. 1. Diagram Partisipasi Masyarakat

Sumber : dokumentasi pribadi

\section{Metode Penelitian}

Penelitian ini adalah penelitian evaluasi, dimana akan ditemukan temuan-temuan yang terkait dengan partisipasi masyarakat lokal dalam pengembangan Ekowisata di kawasan Tangkahan yang memadukan metoda kualitatif dan metoda kuantitatif. Metoda kualitatif dilakukan dengan cara observasi, wawancara, dan dokumentasi. Metoda kuantitatif dilakukan dengan cara penyebaran kuesioner terhadap wisatawan dan masyarakat lokal guna mengetahui persepsi masing - masing mengenai ekowisata di kawasan Tangkahan dengan jumlah sampel sebanyak 200 responden yang terdiri dari 100 masyarakat lokal dan 100 wisatawan yang terdiri dari 60 wisatawan lokal dan 40 wisatawan asing. Metoda kualitatif dilakukan untuk mengetahui kondisi dan situasi mengenai partisipasi masyarakat lokal di kawasan Tangkahan yang kemudian diperkuat dengan adanya metoda kuantitatif agar penelitian tidak subjektif karena sudah melibatkan persepsi dari wisatawan dan masyarakat lokal. Untuk menentukan jumlah sampel yang diambil, peneliti menjabarkan beberapa penelitian yang telah dilakukan jurnal "analisis potensi dan arahan strategi kebijakan pengembangan desa ekowisata di kecamatan bumiaji - kota batu" mengambil sampel sebanyak 7 sampel untuk diwawancarai sebagai informan kunci dan jurnal "strategi pengembangan ekowisata mangrove di kawasan pantai tanjung bara, kutai timur, Kalimantan timur" menggunakan sampel sebanyak 5 sampel untuk diwawancarai sebagai informan kunci. Berdasarkan jurnal tersebut, maka peneliti menggunakan sampel sebanyak 7 sampel untuk diwawancarai sebagai informan kunci yaitu ketua pengelola kawasan ekowisata tangkahan, masyarakat lokal sekitar kawasan tangkahan (pemilik penginapan, tourguide, dan pawang gajah (mahout), dinas pariwisata langkat dan direktur CRU (Conservation Response Unit). 


\section{Analisa dan Pembahasan}

\subsection{Otoritas yang mengorganisir kawasan ekowisata}

Partisipasi masyarakat sangat penting dalam mengelola Ekowisata. Partisipasi masyarakat sangat penting dalam pengelolaan kawasan Ekowisata dikarenakan dapat berpengaruh pada pendapatan bagi masyarakat itu sendiri. Pada kawasan Tangkahan, partisipasi masyarakat sudah berjalan dengan baik, dapat dilihat dari ketersediaan layanan dan jasa. Tidak hanya itu , dalam mengelola Ekowisata masyarakat di Tangkahan ini memiliki pendapatan yang juga sangat baik (table 1).

Tabel 1. Aspek Otoritas yang mengorganisir kawasan Ekowisata

\begin{tabular}{clc}
\hline \multicolumn{1}{c}{ Aspek } & \multicolumn{1}{c}{ Pertanyaan } & $\begin{array}{c}\text { Mean } \\
\text { (Masyarakat) }\end{array}$ \\
\hline \multirow{2}{*}{$\begin{array}{c}\text { Otoritas yang mengorganisir } \\
\text { kawasan ekowisata }\end{array}$} & Terciptanya lapangan kerja dengan adanya Ekowisata & 2,90 \\
& Tangkahan & 4,05 \\
& Adanya pembagian tugas dalam mengatur kegiatan & 3.54 \\
& Ekowisata di Tangkahan & 4,09 \\
& Masyarakat ikut serta dalam hal mengkonservasikan alam & \\
& di Tangkahan & \\
\hline
\end{tabular}

\subsubsection{Adanya Hukum Sehingga Lingkungan Kondusif}

Lembaga sebagai suatu organisasi yang dibentuk oleh atau ada hubungannya dengan pemerintah dan atau terdaftar pada Lembaga Negara serta memiliki aturan-aturan formal seperti Anggaran Dasar (AD) dan Anggaran Rumah Tangga (ART). Di Tangkahan, selain mengkonservasi flora dan fauna yang ada di Tangkahan dengan cara berpatroli, masyarakat lokal juga berinisiatif untuk membentuk Polisi Hutan (PolHut) untuk menghindari serta meminimalisir ancaman kriminalitas hutan yang kerap menjadi permasalahan di Indonesia ini yang dikarenakan banyaknya pemburu - pemburu liar yang mementingkan diri sendiri dengan cara memburu hewan - hewan untuk diambil anggota tubuhnya lalu dijual. Selain membentuk badan hukum seperti polisi hutan (PolHut) untuk menghindari adanya ancaman terhadap alam sekitar Tangkahan, Kementrian Kehutanan RI juga memasang peringatan tentang dilarang memburu hewan dan tumbuhan di dalam hutan Tangkahan ini. Bagi yang melanggar akan dikenakan pidana paling lama 10 tahun dan dena paling banyak Rp. 5.000.000.000 (lima milyar rupiah). Dari hasil wawancara peneliti pada saat di lapangan dapat diketahui bahwa untuk menyukseskan penegakan peraturan ini, disediakan pamphlet besar yang berfungsi sebagai "pengingat" untuk warga yang berniat melakukan penebangan hutan secara liar." Pamphlet besar ini diletakkan disini agar masyarakat tidak sembarangan menebang pohon karena ada peraturan karena polhut tidak selalu berpatroli disini untuk mengawasi. Pamphlet ini berfungsi untuk mengurungkan niat para pembalak kayu dan pemburu liar untuk tidak melanggar peraturan yang ada dikarenakan adanya denda dan hukuman pidana bagi yang melanggar peraturan." (informan kunci : Tour Guide).

Hal ini sejalan dengan hasil kuesioner masyarakat lokal mengenai adanya hukum yang terdapat pada kawasan Tangkahan ( 2,90 ) yang membuktikan bahwa mayoritas masyarakat setuju dengan pertanyaan bahwa adanya hukum di kawasan Tangkahan yang menjadikan kawasan ini kondusif. (Tabel 1) (gambar 2)

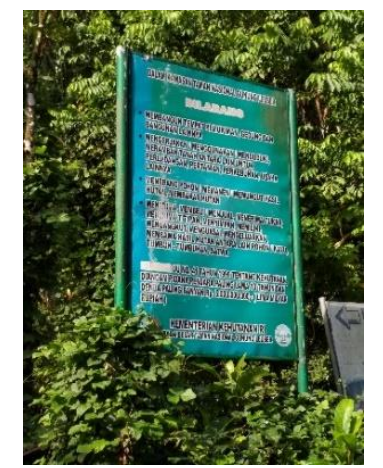

Gambar 2. Pamphlet peringatan

Sumber : dokumentasi pribadi 


\subsubsection{Adanya Pembagian Tugas}

Institusi atau suatu organisasi pada suatu kawasan bertugas untuk menciptakan lingkungan politik dan hukum yang kondusif, sektor swasta membuka lapangan pekerjaan dan memberikan pendapatan, serta masyarakat yang berperan dalam membangun interaksi sosial, ekonomi, dan politik serta mengorganisir seluruh kegiatan yang ada pada suatu kawasan Ekowisata. Di Tangkahan, suatu bentuk keberhasilan pengelolaan Ekowisata ini memiliki unit kantor CTO (Community Tour Operator) dalam memberikan informasi seputar kawasan Ekowisata Tangkahan. Kantor ini terdiri dari ketua, pegawai serta tour guide yang digunakan berasal dari masyarakat kawasan itu sendiri dan dipilih oleh masyarakat kawasan itu juga. Wisatawan dapat mengetahui informasi baik dalam hal tarif wisata, informasi wisata apa saja yang dapat dikunjungi, bahkan penginapan bisa ditanyakan di kantor ini. Selain Kantor CTO Tangkahan juga memiliki CRU (Conservation Response Unit) yang dikelola oleh masyarakat juga namun bermitra dalam konservasi gajah serta informasi seputar gajah. Pada CRU ini terdiri dari pegawai, pawang gajah, penjaga suvenir, serta yang membuat suvenir adalah masyarakat kawasan Ekowisata Tangkahan.

Hal ini ditegaskan dengan wawancara peneliti pada saat dilapangan "Ditangkahan ini memiliki unit kantor CTO dalam mengatur informasi terkait wisata tangkahan dan unit dalam konservasi gajah yang disebut CRU. Kedua kantor tersebut di kelola oleh masyarakat”. (Informan kunci : ketua CTO).

Hal ini didukung dengan hasil kuesioner masyarakat lokal mengenai adanya pembagian tugas dalam pengelolaan kawasan Ekowisata Tangkahan ( 3,54 ) yang dapat memperkuat data hasil observasi diatas bahwa pembagian tugas yang terdapat pada kawasan Tangkahan sudah sangat terorganisir dengan baik dan terdapat pembagian tugas yang merata dari pihak pengelola. (Tabel 1)(gambar 3)

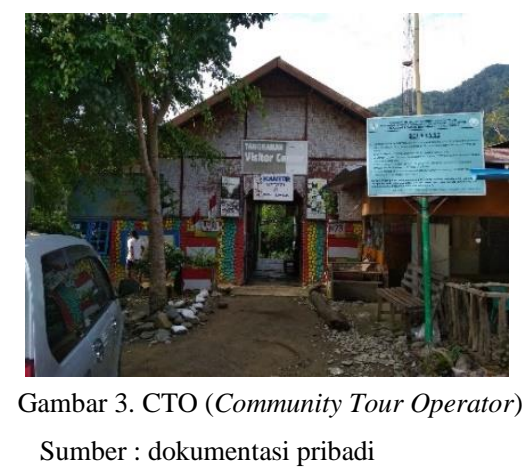

\subsubsection{Terciptanya Lapangan Kerja}

Peluang keterlibatan masyarakat akan menjadikan masyarakat diberdayakan dan melaksanakan fungsi kontrol dari tindakan para pengambil keputusan agar bertanggung jawab serta dapat pula mempertanggungjawabkan keputusan-keputusan mereka. Hal ini pada akhirnya akan berdampak positif bagi upaya pemberantasan korupsi, peningkatan pelayanan, dan memastikan bahwa sumber daya digunakan secara efisien. Dengan berkembangnya kawasan ekowisata Tangkahan, semakin banyak lapangan kerja yang tercipta. Hal ini tentu saja dapat mensejahterakan masyarakatnya sehingga tindakan kriminalitas di kawasan Tangkahan menjadi sedikit. Dulunya masyarakat Tangkahan mendapatkan penghasilan dari berkebun dan illegal logging, namun sekarang dengan berkembangnya kawasan ekowisata ini, banyak jenis pekerjaan lain yang tersedia seperti staf kantor, penjaga penginapan, pengelola kawasan Tangkahan, pawang gajah (mahout), Tour Guide dan petugas kebersihan. Selain itu, masyarakat lokal juga dapat berwira usaha seperti membuka rumah makan ataupun menjual hasil sourvenir khas Tangkahan. "Kalau bisa pemanfaatan sumber daya manusia seperti masyarakat lokal itu yang diutamakan, banyak masyarakat ditempat wisata lain, kurang dukungan dari wisata lokal, karena enggak merasa mendapatkan keuntungan secara ekonomi kebanyakan pemainnya dari orang lain, sehingga masyarakat lokal hanya jadi penonton. Di Tangkahan hampir 90 persen masih muatan lokal" (Informan kunci : ketua CTO). Hasil dari kuesioner masyarakat lokal terkait terciptanya lapangan kerja dengan adanya Ekowisata Tangkahan ( 4,05) yang membuktikan bahwa mayoritas masyarakat sangat setuju bahwa terciptanya lapangan kerja membantu masyarakat dalam perekonomian untuk memenuhi kebutuhan sehari - harinya. (Tabel 1.)(gambar 4)

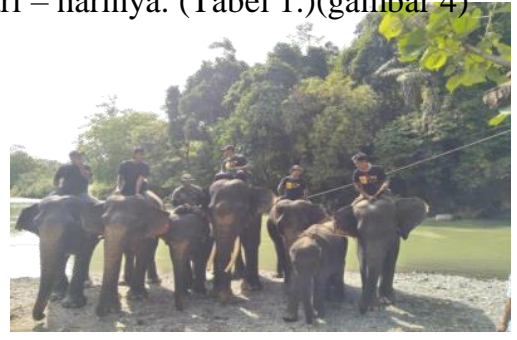

Gambar 4. Pawang Gajah (Mahout)

Sumber : dokumentasi pribadi 


\subsubsection{Upaya Konservasi}

Pengelolaan dari organisasi terhadap suatu ekowisata menerapkan pendekatan konservasi terhadap lingkungan sehingga alam sekitar Ekowisata tetap terjaga. Di Tangkahan, konservasi terbagi dalam dua cara. Yang pertama adalah melakukan pengelolaan wisatawan. Pengelolaan dilakukan dengan cara pendataan. Pendataan ini berfungsi untuk mengontrol jumlah wisatawan yang datang agar alam tidak rusak dikarenakan ramainya aktivitas pengunjung. Pendataan dilakukan dengan cara menuliskan data diri pada kertas yang tersedia di kantor CTO. Yang kedua, konservasi pada flora dan fauna. Konservasi pada flora dan fauna dilakukan dengan cara berpatroli ke hutan untuk memantau keadaan serta menjaga agar flora dan fauna yang ada dihutan tidak diburu dan di eksploitasi secara berlebihan oleh orang yang tidak bertanggung jawab serta mengadakan pertukaran petugas kebersihan sebulan sekali yang terdiri dari 4 wanita dan 4 pria yang memiliki tugas masing - masing. Dari hasil wawancara dengan salah satu guide, dapat diketahui bahwa masyarakat lokal yang memantau keadaan didalam hutan Taman Nasional Gunung Leuser untuk mencegah pemburu liar. "Masyarakat lokal sering untuk berpatroli ke dalam hutan Taman Nasional Gunung Leuser untuk memantau keadaan di dalam hutan dan mencegah adanya pembalakan kayu dan pemburu liar yang ada didalam hutan" (informan kunci :, Tour Guide).

Hal ini didukung dengan kuesioner yang disebarkan kepada masyarakat lokal mengenai masyarakat ikut serta dalam hal mengkonservasi alam di Tangkahan ( 4,09 ) yang membuktikan bahwa masyarakat di Tangkahan tidak hanya memanfaatkan kawasan Tangkahan sebagai sumber pendapatan namun mereka juga ikut menjaga alam yang ada di Tangkahan sehingga alam tersebut masih tetap terjaga dan alami. (Tabel 1) (gambar 5)

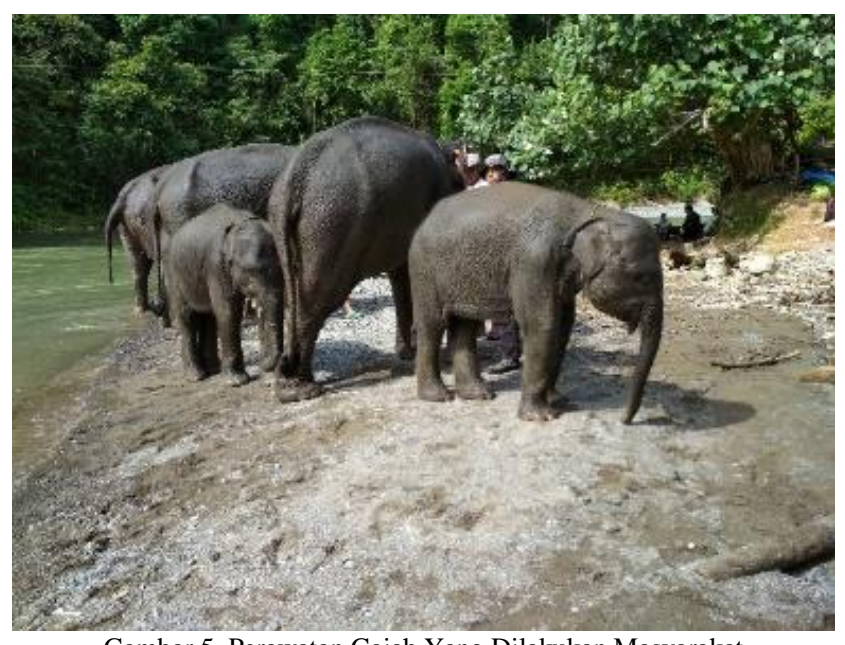

Gambar 5. Perawatan Gajah Yang Dilakukan Masyarakat

Sumber : dokumentasi pribadi

Dapat disimpulkan bahwa aspek otoritas yang mengorganisir kawasan ekowisata Tangkahan, pihak pengelola sudah sangat baik dalam mengelola kawasan Tangkahan ini. Hal ini dibuktikan dengan terciptanya banyak lapangan kerja bagi masyarakat dengan adanya ekowisata, pembagian tugas yang merata dari pihak pengelola kepada masyarakat, dan masyarakat ikut serta dalam mengkonservasi alam yang ada di Tangkahan. Namun, menurut masyarakat lokal, hukum di Tangkahan dinilai kurang cukup untuk menciptakan kawasan yang kondusif.

\subsection{Keterlibatan masyarakat lokal dalam perencanaan, pelaksanaan, pemantauan, serta evaluasi kawasan ekowisata}

Keterlibatan masyarakat didalam kawasan Ekowisata termasuk dalam perencanaan, pelaksanaan, pemantauan, serta evaluasi kegiatan ekowisata yang ada pada suatu kawasan. Di Tangkahan, masyarakat terlibat dalam perencanaan, pelaksanaan, pemantauan, serta evaluasi kegiatan ekowisata yang ada disini. Kurangnya keterlibatan masyarakat dalam perencanaan, implementasi, dan pengambilan keputusan dalam pengembangan ekowisata dapat menghambat masyarakat untuk mendapatkan manfaat lebih banyak. Keterlibatan masyarakat dapat dicapai dengan meningkatkan kemampuan masyarakat. Dengan adanya keterlibatan masyarakat lokal, masyarakat lokal dapat merasakan dampak langsung dari ekowisata (table 2). 
Tabel 2 Aspek Keterlibatan Masyarakat Dalam Perencanaan, Pelaksanaan, Pemantauan, Serta Evaluasi

\begin{tabular}{lll}
\hline \multicolumn{1}{c}{ Aspek } & \multicolumn{1}{c}{ Pertanyaan } & $\begin{array}{c}\text { Mean } \\
\text { (Masyarakat) }\end{array}$ \\
\hline Keterlibatan & Adanya rapat evaluasi yang diadakan pihak pengelola & 3.27 \\
masyarakat dalam & untuk mengevaluasikan kekurangan apa saja & \multicolumn{1}{c}{ didalamnya melayani wisatawan } \\
perencanaan, & Masyarakat lokal ikut serta dalam perencanaan & 3,50 \\
pelaksanaan, & kawasan Tangkahan sehingga menjadikan kawasan & 3,07 \\
pemantauan, serta & Ekowisata & Masyarakat lokal ikut serta dalam pelaksanaan \\
Ekowisata & kegiatan Ekowisata di Tangkahan & 3,43 \\
& Masyarakat lokal ikut serta pemantauan kegiatan & 2,36 \\
& Ekowisata di Tangkahan & \\
& Adanya pertunjukan lokal yang diberikan masyarakat & \\
\hline
\end{tabular}

\subsubsection{Masyarakat terlibat dalam perencanaan, pelaksanaan, pemantauan, serta evaluasi}

Masyarakat sangat setuju untuk ikut serta dalam hal mengkonservasikan alam di Tangkahan $(4,09)$. Masyarakat setuju untuk ikut serta dalam perencanaan kawasan Tangkahan sehingga menjadikan kawasan Ekowisata (3,50). Masyarakat lokal ikut serta dalam pelaksanaan kegiatan Ekowisata di Tangkahan $(3,07)$. Masyarakat lokal ikut serta dalam pemantauan kegiatan Ekowisata di Tangkahan (3,43).(Tabel 1.2)

Keterlibatan masyarakat dalam perencanaan akan menciptakan hasil yang lebih baik, sehingga rasa tanggung jawab bersama akan terbina yang nantinya menghasilkan kerja yang lebih baik. Masyarakat di sekitar Tangkahan setuju untuk memiliki keterlibatan pada ekowisata. Hal ini dapat dilihat dari respon masyarakat pada kuesioner yang diberikan. Hal ini menjadi membuktikan bahwa partisipasi masyarakat sudah cukup baik, sehingga perlu dipertahankan dan ditingkatkan (gambar 6)

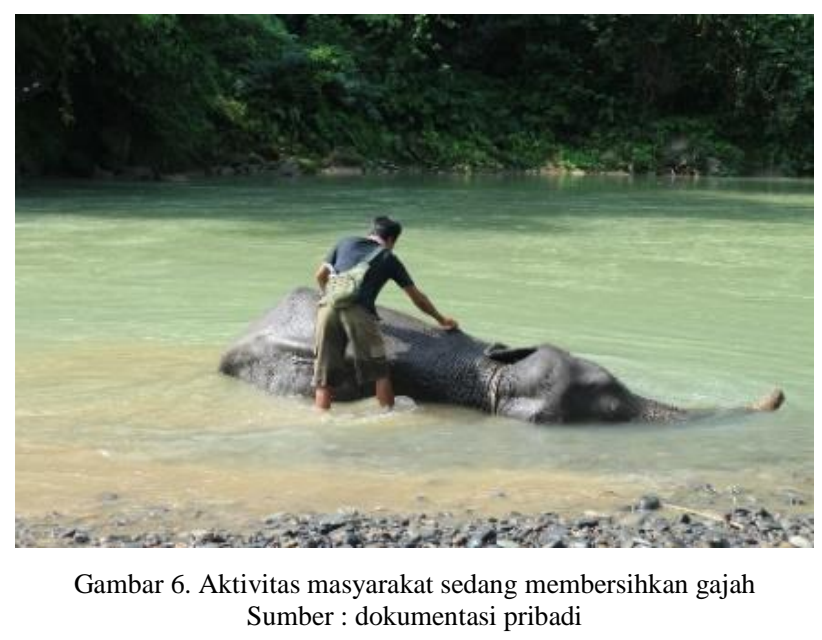

\subsubsection{Pemantauan terhadap budaya lokal}

Masyarakat berpendapat kurangnya pertunjukan lokal yang diberikan masyarakat local terhadap wisatawan (2,36). Hal ini dapat dilihat dengan kurangnya pertunjukan yang diberikan masyarakat lokal terhadap wisatawan. Budaya tersebut masih ada di masyarakat namun tidak menjadi atraksi utama pada wisata.(Tabel 1.2)

Keterlibatan masyarakat dalam pemantauan aktivitas pada kawasan ekowisata meliputi juga pemantauan terhadap budaya - budaya lokal yang terdapat pada kawasan. Pengawasan terhadap budaya - budaya ini dimaksudkan untuk menghindari hilangnya kebudayaan asli sekitar kawasan. Berdasarkan tanggapan responden, kurangnya pengawasan terhadap unsur budaya pada wisata 
Tangkahan dapat mengancam keberadaan kebudayaan asli di kawasan Tangkahan. Diperlukan pengawasan yang lebih baik agar unsur budaya masyarakat lokal tetap ada.

Dapat disimpulkan bahwa aspek keterlibatan masyarakat, masyarakat Tangkahan sudah sangat baik partisipasinya. Hal ini ditandai dengan adanya partisipasi masyarakat dalam perencanaan, pelaksanaan, pemantauan, dan evaluasi kawasan Ekowisata Tangkahan. Namun, masyarakat lokal menilai bahwa budaya lokal yang ada di Tangkahan kurang dilestarikan dan dipertunjukkan bagi wisatawan yang datang ke Tangkahan.

\subsection{Layanan jasa dari masyarakat lokal}

Masyarakat lokal dalam mengelola ekowisata sangatlah penting karena masyarakat lokal merupakan kunci dalam pengembangan ekowisata dimana berperan sebagai penyedia atraksi wisata dan penentu kualitas produk wisata tersebut. Dalam meningkatkan suatu ekowisata dapat diperlunya suatu layanan jasa: (a) Layanan Jasa dalam bentuk tenaga_Peranan dan keterlibatan masyarakat dalam mengelola seperti pemandu maupun memasarkan produk-produk ekowisata yang dikelola oleh suatu kawasan ; (b) Layanan Jasa dalam bentuk ketrampilan: Meningkatkan peran dan partisipasi masyarakat dalam memanfaatkan sumber daya yang ada untuk dijadikan sebuah usaha dengan tujuan memperoleh keuntungan ekonomi, sosial, maupun budaya dari pembangunan ekowisata. (table 3)

Tabel 3 Aspek Layanan Jasa Dari Masyarakat Lokal

\begin{tabular}{|c|c|c|c|}
\hline \multirow[t]{2}{*}{ Aspek } & \multirow[t]{2}{*}{ Pernyataan } & WL & WA \\
\hline & & Mean & Mean \\
\hline \multirow{12}{*}{$\begin{array}{l}\text { Layanan Jasa Dari } \\
\text { Masyarakat Lokal }\end{array}$} & Atraksi ditempat ini menarik. & 3.12 & 2.88 \\
\hline & Harga penginapan ditempat ini terjangkau. & 3.07 & 4.13 \\
\hline & Penginapan ditempat ini nyaman dan bersih. & 3.08 & 3.46 \\
\hline & Harga makanan yang terjangkau. & 3.13 & 3.88 \\
\hline & Tempat makan ditempat ini nyaman dan bersih. & 2.92 & 3.25 \\
\hline & Harga sourvenir ditempat ini terjangkau. & 2.12 & 3.53 \\
\hline & Sourvenir ditempat ini bagus. & 2.98 & 3.43 \\
\hline & Toilet ditempat ini mudah ditemukan. & 2.80 & 3.08 \\
\hline & Visitor center ditempat ini mudah ditemukan. & 3.48 & 4.35 \\
\hline & Tour guide ditempat ini membantu wisatawan. & 3.6 & 4.43 \\
\hline & Tempat sampah ditempat ini mudah ditemukan. & 2.53 & 2.75 \\
\hline & Jumlah tempat sampah ditempat ini memadai. & 2.53 & 2.58 \\
\hline
\end{tabular}

\subsubsection{Atraksi wisata}

Tangkahan juga terdapat banyak gajah-gajah, Atraksi disebut merupakan komponen yang signifikan dalam menarik wisatawan, atraksi merupakan modal utama (tourism resources) atau sumber dari kepariwisataan. Gajah-gajah di kawasan ini bukanlah untuk atraksi wisata, melainkan untuk membantu polisi hutan berpatroli memberantas pembalak liar. Adapun kegiatan dalam memandikan serta memberikan makan terhadap gajah tidak menjadikan objek tersebut sebagai atraksi. Dipertegas dari hasil wawancara "tidak ada atraksi yang di tawarkan terhadap wisatawan hanya saja saat memandikan dan memberi makan gajah wisatawan hanya dapat berfoto ria dengan gajah dan dapat menungganginya keliling lokasi sekitar wisata Tangkahan” (informan kunci : ketua CTO)

Mengenai hasil kuesioner aspek atraksi wisata, wisatawan lokal sangat setuju bahwa d atraksi yang terdapat pada kawasan Tangkahan menarik $(3,12)$. Berbeda dengan penilaian wisatawan lokal, wisatawan asing menilai kurang setuju bahwa atraksi yang tersedia di kawasan Tangkahan ini kurang menarik $(2,88)$. Dari data diatas, dapat disimpulkan bahwa atraksi yang terdapat pada kawasan Tangkahan kurang menarik bagi wisatawan asing. (Tabel 3) (gambar 7) 


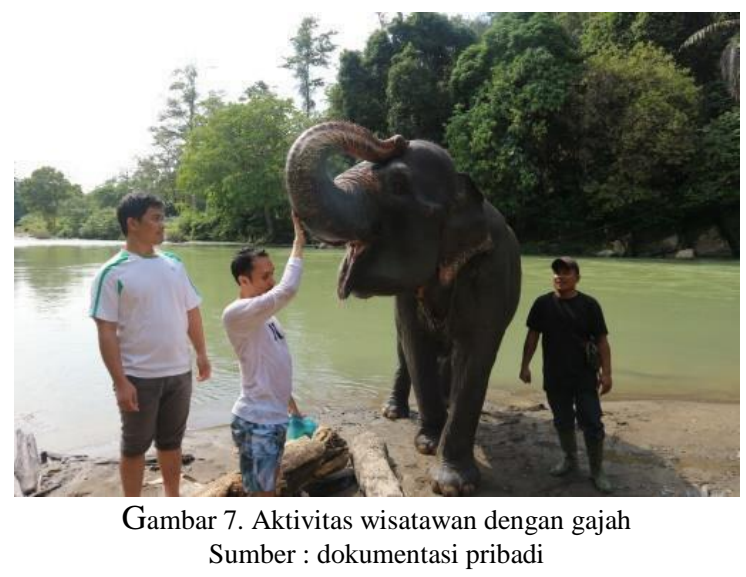

\subsubsection{Pemandu}

Salah satu aspek dari partisipasi masyarakat adalah adanya layanan atau jasa yang diberikan kepada wisatawan dari masyarakat local sesuai dengan tugasnya masing-masing. "mempunyai 120 pekerja yang terbagi 3 bagian yaitu: 40 tim konservasi, 40 tim SAR, dan 40 tim pemandu (informan kunci:, Tour Guide). Salah satunya tim konservasi bertugas untuk berpatroli ke dalam hutan untuk menghindari adanya pemburuan liar, tim SAR bertugas untuk menjaga keamanan para wisatawan khususnya di daerah rawan seperti di area yang memiliki aliran sungai yang kuat, dan tim pemandu yang bertugas untuk memandu wisatawan ke dalam hutan serta memandu wisatawan untuk berinteraksi langsung dengan gajah - gajah yang menjadi daya tarik di Tangkahan. Mengenai aspek pemandu pada kawasan Tangkahan, terdapat pendapat yang sama dari wisatawan lokal dan wisatawan asing. Wisatawan lokal menilai tour guide cukup membantu wisatawan yang datang ke Tangkahan (3.6) sedangkan menurut wisatawan asing, tour guide di Tangkahan ini sangat membantu wisatawan yang datang berkunjung (4.43). Berdasarkan data diatas, dapat disimpulkan bahwa menurut wisatawan asing, tour guide atau pemandu di kawasan Tangkahan ini sangat membantu (Tabel 1.3).

\subsubsection{Layanan Jasa Yang Bagus}

\section{- Penginapan}

Di kawasan tangkahan ini wisatawan tidak perlu khawatir mengenai penginapan dan rumah makan karena sudah terdapat banyak penginapan beserta rumah makan di kawasan ini. Kawasan ekowisata tangkahan sudah memenuhi kriteria tersebut dengan adanya berbagai jenis penginapan dan rumah makan yang ditemui di kawasan tersebut. Penginapan dikawasan tangkahan dibagi menjadi dua daerah dimana yang pertama terdapat di kawasan yang biasa disebut Lau Buluh dan yg kedua terdapat di kawasan Tangkahan sendiri. Penginapan yang berada di kawasan Lau Buluh ini terdapat 5 penginapan yaitu Mega Inn dengan tersedianya 20 kamar , Bamboo River dengan tersedianya 11 kamar, Dream Land, Jungle Lodge dengan tersedianya 20 kamar, dan Linea Ressort dengan tersedianya 8 kamar. Sedangkan di kawasan tangkahan sendiri terdapat 4 penginapan yaitu Green Forest Tangkahan, Mountain View Cottages \& Restaurant, Tangkahan Inn dengan tersedianya 8 kamar dan Green Lodge (gambar 8).

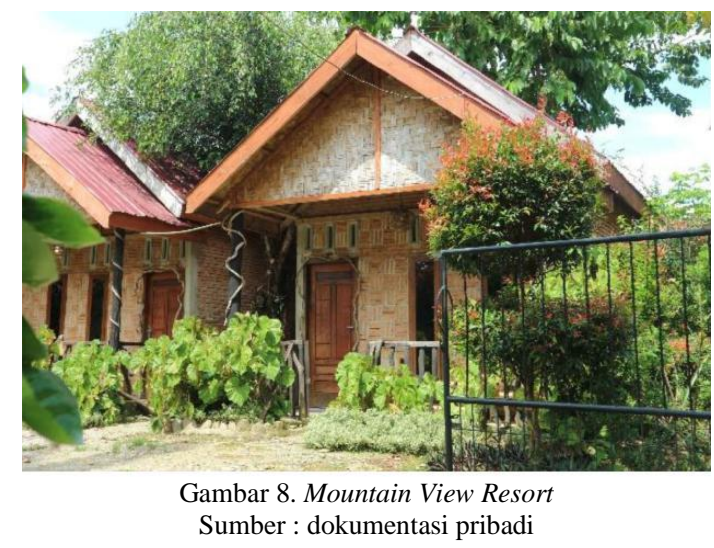

"Kalau di Jungle Load ada dua jenis kamar dari 20 kamar yang disediakan. Kamar untuk 2 orang berisi tempat tidur double bed Rp 150.000 perkamar, apabila untuk 3-4 orang dikenakan biaya Rp 200.000 perkamar, extra bed dikenakan biaya tambahan Rp 50.000." (informan kunci : Pekerja di Jungle Load)

"Nah kalau di Tangkahan Inn semua tipe kamar sama dengan harga Rp 150.000 per kamar dapat menampung 2 orang pakai double bed, tetapi kalau lebih dari 2 orang dikenakan biaya extra bed Rp 50.000 satunya, sama dengan penginapan lain 34 orang biasanya dikenakan biaya Rp 200.000 per kamarnya”. (informan kunci : Pekerja di Tangkahan Inn). 
Wisatawan lokal menilai bahwa harga penginapan di Tangkahan cukup terjangkau $(3,07)$, penginapan di Tangkahan ini cukup nyaman dan bersih (3.08). Sedangkan wisatawan asing menilai bahwa harga penginapan di Tangkahan sangat terjangkau (4.13), penginapan di Tangkahan nyaman dan bersih (3.46).(Tabel 1.3)

\section{- Rumah Makan}

Dari segi fasilitas rumah makan, untuk rumah makan khusus berdasarkan hasil observasi, memang belum tersedia secara khusus rumah makan berbintang seperti restaurant dan kebanyakan rumah makan sudah dilengkapi langsung di penginapan, sehingga memudahkan wisatawan untuk mencari makan. Hanya satu rumah makan umum yang berada dikawasan tangkahan ini tepatnya berada disebelah Visitor Centre. Sesuai hasil wawancara yang kami lakukan dengan pemilik Rumah Makan Umum dengan nama Rumah Makan Mbak Nining beliau membuka usaha tersebut untuk memudahkan wisatawan lokal yang hanya 1 hari saja berkunjung ke kawasan ekowisata tangkahan.

"Saya membuka Rumah Makan ini untuk memudahkan wisatawan lokal yang hanya satu hari saja berkunjung, karena banyak wisatawan lokal yang susah mencari makanan. Tidak semua wisatawan nginap disini, biasanya pemuda-pemudi yang datang dari Binjai,Medan pada datang pagi pulang sore,jadi mereka kebingungan untuk mencari makan, kasihan juga saya lihatnya, dengan banyak perjuangan ya akhirnya jadilah Rumah Makan Mbak Nining ini di Tangkahan." (informan kunci : Pemilik Rumah Makan Mbak Nining).

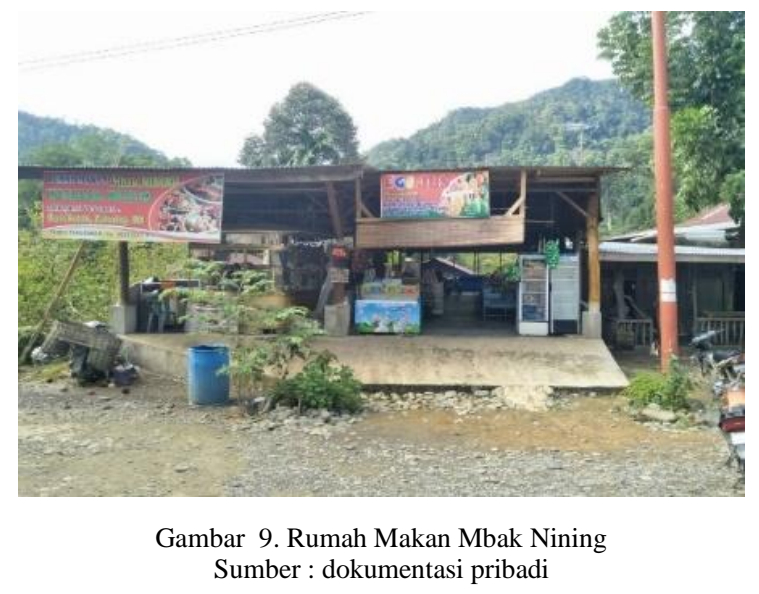

- Toko Suvenir

Pada pengembangan ekowisata harus terdapat unsur wisata yaitu berupa produk atau jasa yang dapat dijual dan menjadi daya tarik bagi wisatawan. Ekowisata Tangkahan juga menyediakan produk yang dijual untuk wisatawan seperti kaos,kalung, tas dan dompet yang dibuat dari bahan daur ulang serta lucky stones yaitu batu pipih berukuran kecil yang dicat dengan karakterkarakter berbeda. Berdasarkan hasil wawancara dengan pegawai yang berada di CRU sebagian produk yang di jual adalah hasil kerajinan masyarakat lokal untuk membantu ekowisata kawasan tangkahan. “Disini sebagian produk yang kami jual hasil kerajinan tangan masyarakat setempat untuk membantu kemajuan tangkahan ini. Ibu-ibu dan pemudi kawasan ini membuat tas dan dompet dari bahan-bahan yang dapat di daur ulang, seperti plastik plastik bekas detergen,shampoo,sabun,dsb dimanfaatkan oleh kami disini untuk menghasilkan produk yang menarik." (informan kunci : pegawai CRU)

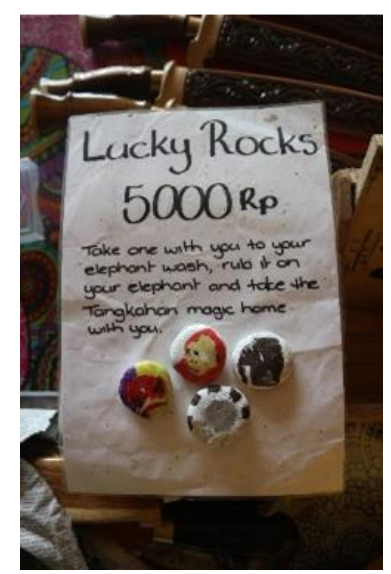

Gambar 10. Lucky Rocks

Sumber : dokumentasi pribadi 
Wisatawan lokal menilai bahwa harga suvenir di Tangkahan juga kurang terjangkau (2.12), suvenir di Tangkahan juga dinilai kurang bagus (2.98). Sedangkan wisatawan asing menilai bahwa harga suvenir cukup terjangkau (3.53), dan suvenir di Tangkahan dinilai cukup bagus (3.43). (Tabel 3)

\section{- $\quad$ Toilet Umum}

Wisatawan lokal dan wisatawan asing memiliki presepsi yang sama mengenai toilet umum di tangkahan sulit ditemukan dan toilet umum di tangkahan kurang bersih dan nyaman. Hal ini didukung dengan kuiseoner wisatawan lokal yang menilai toilet umum di tangkahan sulit ditemukan $(2,80)$ serta wisatawan asing yang menilai toilet umum di tangkahan sulit ditemukan $(3,08)$. (Tabel 3)

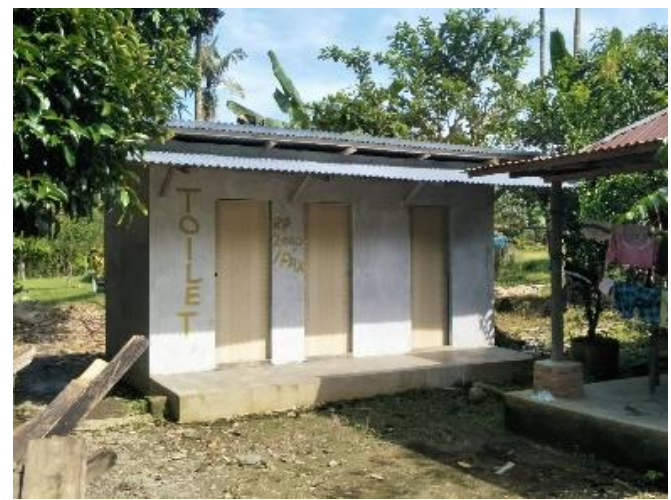

Gambar 11. Toilet Umum

Sumber : dokumentasi pribadi〉

\section{- $\quad$ Visitor Center}

Setiap wisatawan yang hadir disambut dengan hangat oleh masyarakat setempat. Tersedianya kantor CTO ( Community Tour Operator) atau LPT ( Lembaga Pengelolahan Tangkahan ) atau dengan nama Visitor Centre yang terdapat setelah kita melewati pintu masuk kawasan ekowisata adalah salah satu cara membantu wisatawan yang hadir ke kawasan tersebut. Ekowisata harus memiliki ciri khas yaitu bersifat ramah terhadap pengunjung, seperti halnya memiliki komunikasi yang baik. Dari hasil wawancara kepada ketua kantor pengelola ekowisata Tangkahan adanya kantor ini dibuat agar wisatawan tidak kebingungan untuk melakukan apa saja di kawasan ekowisata tangkahan. Wisatawan juga bisa bertanya mengenai penginapan, restoran, tempat ibadah, dan sebagainya. Khusus wisatawan mancanegara sebelum memulai kegiatan di kawasan ekowisata tangkahan, diwajibkan mengisi formulir khusus, formulir ini dibuat agar pihak kantor dapat mengetahui identitas wisatawan sebenarnya dan dapat mencegah halhal yang negatif dari wisatawan. "Kantor ini dibuat untuk mempermudah wisatawan untuk melakukan ekowisata di kawasan ini apalagi wisatawan yang datang kesini hampir rata-rata wisatawan mancanegara, karena itu mereka mengisi formulir dahulu sebelum melakukan kegiatan ekowisata disini, karena khawatir status mereka tidak jelas atau mungkin bisa jadi teroris. kalau mereka sudah mengisi formulir inikan kita udah dapat identitasnya agar kalau terjadi sesuatu kita bisa langsung hubungi ke pihak yang berwajib" (informan kunci : Ketua Pengelola Ekowisata Tangkahan).

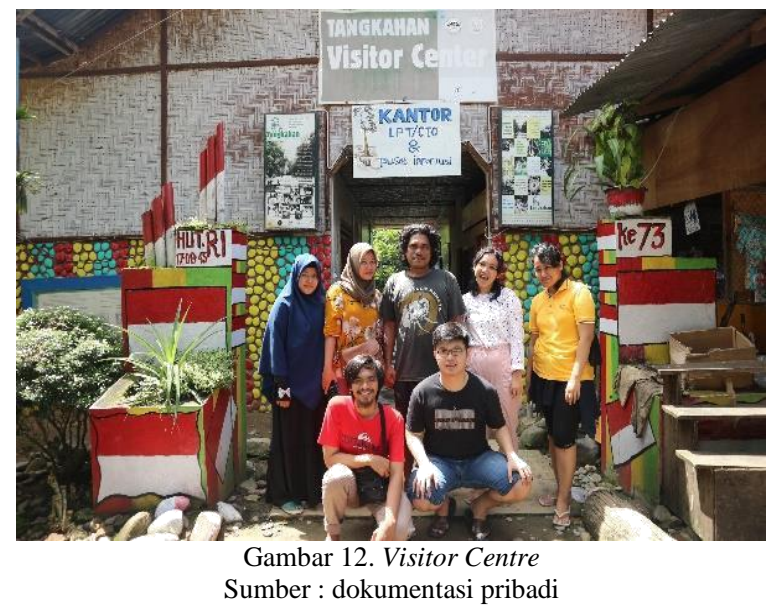


- Tempat Sampah

Untuk tempat sampah, wisatawan asing dan wisatawan lokal setuju bahwa tempat sampah yang terdapat pada kawasan Tangkahan ini kurang memadai jumlahnya dan penempatan tempat sampah yang sulit ditemukan bagi wisatawan.

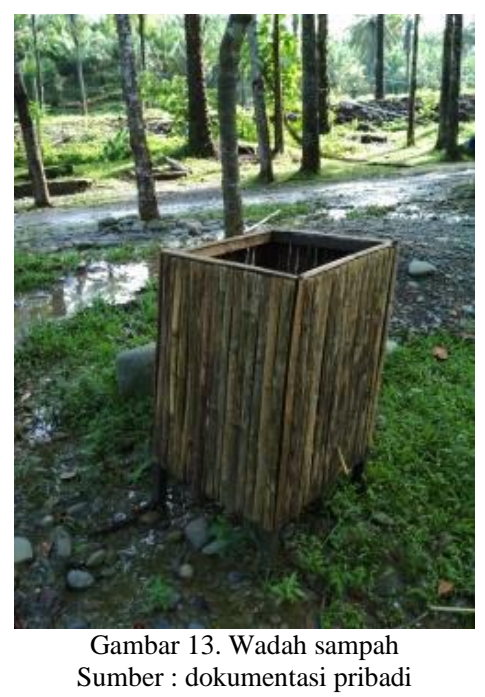

Dapat disimpulkan dari aspek layanan jasa dari masyarakat bahwa tim pemandu yang disediakan oleh masyarakat lokal respon masyarakat terhadap hal tersebut sudah sangat baik dan setuju adanya keterlibatan tim pemandu sebagai pemantau kegiatan. Hal ini sudah cukup baik dalam mempertahankan dan meningkatkan kembali mutu guna untuk mengembangkan Ekowisata Tangkahan. Dari data yang dihasilkan bahwasannya masyarakat merespon kurang adanya kegiatan seperti atraksi saat kegiatan berlangsung, seperti atraksi gajah yang ditawarkan. Hal ini dapat menimbukan rasa bosan wisatawan. Peneliti merekomendasi Ada baiknya atraksi dapat ditampilkan sehingga wisatawan mampu merasakan hal yang mengejutkan saat melihat gajah saat atraksi. Hal ini mampu menciptakan guna mempertahankan dan meningkatkan tempat Tangkahan sebagai objek wisata yang dapat menampilkan tidak hanya keutuhan alam namun wisata yang ditawarkanpun menarik dengan tambahan adanya atraksi.

Toilet umum di kawasan Tangkahan juga kurang di perhatikan kebersihan dan kenyamanannya serta penempatan toilet umum yang sulit ditemukan bagi wisatawan. Tempat sampah juga kurang memadai jumlahnya dan penempatan tempat sampah yang sulit ditemukan wisatawan.

\section{Kesimpulan dan Saran}

Partisipasi masyarakat pada kawasan Tangkahan sudah sangat baik dilaksanakan oleh pihak pengelola maupun masyarakat lokalnya sendiri. Namun, ada beberapa kekurangan yang masih perlu dievaluasi dan diperbaiki oleh pihak pengelola kawasan Tangkahan. Kekurangan tersebut meliputi budaya lokal yang masih kurang dipertunjukkan kepada wisatawan, penempatan toilet dan kebersihan toilet yang belum memenuhi standar, dan tempat sampah yang sulit ditemukan dan jumlah tempat sampah yang masih kurang. Partisipasi masyarakat merupakan aspek penting yang mempengaruhi suksesnya suatu kawasan Ekowisata sehingga peneliti menyarankan agar adanya penelitian lebih lanjut mengenai budaya lokal, dan kualitas fasilitas - fasilitas umum yang terdapat pada kawasan Tangkahan.

\section{Referensi}

[1] Mahdayani, Wiwik. (2009). "Ekowisata : Panduan Dasar Pelaksanaan.” Uhjak

[2] Nurpeni. (2015). "Partisipasi Masyarakat Dalam Pelaksanaan Pengembangan Kawasan Ekowisata." Jurnal Kajian Politik dan Masalah Pembangunan.

[3] Lopez, Mendez dkk. (2014). "Local Participation In Biodervisity Conservation Initiatives.” Elsevier.

[4] Sumarto, Hetifah Sj. (2009). "Inovasi, Partisipasi, Dan Good Governance: 20 Prakarsa Inovatif Dan Partisipatif Di Indonesia.” Jakarta: Yayasan Obor Indonesia.

[5] Yulianda F. (2007). "Ekowisata Bahari Sebagai Alternatif Pemanfaatan Sumberdaya Pesisir Berbasis Konservasi.” Makalah Seminar Sains.

[6].Wells, M., Brandon,K.1 and Hannah,L. (1992). "People and Parks.Linking Protected Area Management with Local Communities." Washington,D.C: WorldBank/WWF/USAID.

[7].Bergh, Gina, Marta Foresti, Alina Rocha Menocal, danLeni Wild. (2012). "Building Governance Into A Post-2015 Framework: Exploring Transparency and Accountability As An Entry Point." London: Overseas Development Institute.

[8]Hasibuan, Malayu S.P. (2008). "Manajemen Sumber Daya Manusia." Jakarta: PT.Bumi Aksara.

[9] Rusiani. (2018). "Pemberdayaan Masyarakat Melalui Ekowisata Di Resort Wonolelo, Taman Nasional Gunung Merbabu: Tantangan dan Strategi." Jurnal Pembangunan Wilayah dan Kota.

[10] Sujali. (2008). "Pengelolaan Usaha Jasa Pariwisata Berbasis Pengembangan Masyarakat Pada Kawasan Ubud Bali." Majalah Geografi Indonesia. 
[11] Sastrayuda, G. S. ( 2010). "Hand Out Mata Kuliah Concept Resort And Leisure, Strategi Pengembangan dan Pengelolaan Resort and Leisure."

[12] Amalia, shitta. (2011). "Analisis Faktor-faktor Yang mempengaruhi Kebijakan Devidend Payout Ratio". Skripsi Universitas Diponegoro Semarang

[13] Aziz, Abdul. (2008). "Peran Serta Masyarakat Dalam Upaya Pengembangan Ekowisata Di Kabupaten Pekalongan." Surakarta. 